\title{
Eco-Psychological and Phenomenological Approach to Sustainability
}

\author{
Larry W. Riggs ${ }^{1}$ and Sandra Hellyer-Riggs ${ }^{2}$
}

\begin{abstract}
Our purpose is to show the value of eco-psychology and phenomenology for a cognitive paradigm fostering sustainable development. Our hypothesis is that those fields help lay the groundwork for truly sustainable development. Our method is a review of scholarly and theoretical work on the origins of the modern paradigm that has governed conceptions of development, and on ecopsychology, phenomenology, cognitive science, and sustainable development. Our contribution is a fully informed understanding of psychological and socio-cultural issues relevant to sustainability. The prevailing conception of development derives from the origins of modern science in seventeenthcentury Europe. Francis Bacon and René Descartes elaborated a vision of development, or material progress, based on exploitation of a nature without inherent value, as a source of raw materials for human purposes. Eco-psychology aims to repair the rift between humanity and nature. Our dominant idea of development implies the alienation from nature that makes it difficult to prioritize authentic sustainability. Maurice Merleau-Ponty makes the crucial point that "we can never grasp the world in its totality but we grasp it according to the mode in which we inhabit it" (Merleau-Ponty, 1962, as cited in Buckley, 2013). What will we sustain? How will we negotiate the socio-cultural and psychological obstacles and achieve reconciliation? What are some examples of meaningful, practical movement toward sustainability?
\end{abstract}

Keywords: eco-psychology, phenomenological, sustainability, mindset/paradigm, mindfulness, emotions, healing

\section{Introduction}

The most often used definition of sustainability states that the term means "meeting the needs of the present without compromising the ability of future generations to meet their own needs" (World Commission on Environment and Development, 1987). This definition is satisfactory, in that it links behavior in the present with its effects on the future, and that it implies human interdependence and social justice, in both present and future. What the definition leaves out is explicit acknowledgement that the "needs" considered must include those of the earth, as well as those of humanity as a whole. In fact, these needs are interdependent. We and our needs cannot be separated from the earth and what is required to preserve its capacity to sustain itself and us. Human sustainability requires the sustainability of humanity's relationship with the earth which, ultimately, must supply whatever we choose to define as our "needs." Movement toward a mentality or paradigm acknowledging and serving this interdependence would be, itself, a crucial form of development. It seems to us that this must be included in any adequate definition of sustainability.

The words "sustainable" and "sustainability" are currently both overused and often used in facile ways that ignore the fact that there is much in the dominant modern mindset and the modern conception of development that is incompatible with actual sustainability. We join eco-psychologists in thinking that sustainability is, in fact, a 
cognitive and phenomenological issue, a matter of experiential awareness. It is also, we argue, an emotional issue. This is what eco-psychological and related theories add to most current thinking about sustainability. Sustainability has become of paramount importance precisely because we are not living within the limits that it will require, and our future way of living must be designed and conducted with nature in mind (Buckley, 2013). Bruno Latour (1993) argues that most premodern cultures practiced restraint in their uses of nature because they realized that they could not significantly alter nature without undermining their societies. Refusing to respect that interconnection has led to destructive excess.

\section{Eco-psychology}

The general field of eco-psychology offers much in terms of both a critique of the dominant mindset, or style of cognition, and intimations of what a more "sustainable" mindset would be. Eco-psychologists pose a number of important questions. Why do we not conceive of and inhabit the earth sustainably? Why do we not take seriously the needs of the earth, as well as our own perceived needs and those of other humans? How can we restore the earth, both materially and as a factor in our consciousness, perhaps reconceiving "needs"? What is the mindset that positions us as separate from, and even in a domineering, hostile relation with, the earth? What are the psychological costs of the currently dominant conception of development and of our present relation to the earth? How can "development" be made realistically compatible with sustainability? Can we reimagine what development means in a way that explicitly includes sustaining a mode of consciousness that incorporates and serves the earth's needs? What is it in the background of contemporary consciousness that makes that so difficult? Perhaps the most interesting and crucial question is will sustainability require that a change in awareness come first, or will real steps toward sustainability gradually change our awareness as we seek sustainability? Many such steps are already being taken. Will they lead to true global sustainability?

Eco-psychologists argue that repairing our relationship with the earth will change our paradigmatic way of envisioning development and of defining our needs. The phenomenological, experiential approach, which complements eco-psychology, emphasizes concrete, bodily experience of ourselves in connection with nature as fundamental to the healing process. Our connection to the earth cannot, ultimately, be understood in abstract terms. Such a change in awareness would, indeed, be a vital form of development.

\section{Dominant Conception of Development}

The prevailing modern conception of development, and of our relation to the earth, derives largely from the origins of modern Western science and political thought in seventeenth-century Europe. We note here that sociologist and social philosopher Ulrich Beck (2010) asked whether modernization is synonymous with Westernization. Sir Francis Bacon (1902), in England, and René Descartes (1637), in France, elaborated the epistemological paradigm that eco-feminist Val Plumwood (1993) calls the master model: 
a vision of development, or material progress in achieving narrowly defined human purposes, based on exploitation of a nature unalive and devoid of inherent value. Bacon (1902) advocated treating the world like a witch, torturing from "her" the secrets of successful manipulation. He referred to nature as a "common harlot," (Merchant, 1989, p. 171) and to the new epistemology as a "masculine birth" (Sheldrake, 1994, p. 44). According to Bacon, in his Novum Organum, nature is to be "squeezed and molded" (Bacon, 1620, as cited in Rifkin, 2004, p. 99). David Abram suggests that many moderns consider "a generally exploitative relation to the rest of nature" as "part and parcel of being human" (Abram, 1997, as cited in Buckley, 2013, p. 25). He counters this notion, and instead claims that European civilization's neglect of the natural world and its needs has clearly been encouraged by a style of awareness that disparages sensorial reality, denigrating the visible and tangible order of things on behalf of some absolute source assumed to exist entirely beyond, or outside of, the bodily world (Abram, 1997).

\section{Separation of Mind and Body}

Bacon's epistemological ambition had to do with enhancing the power of King James I, as well as conferring material power over nature on humanity as a whole (Bacon, 1620, as cited in Solomon, 1998). Descartes (1637) touted his method as the means of making man the master and proprietor of the earth, and, in his Meditations (1901), he asserted that he could exist perfectly well without a body. Freedom from constraints, including the body's embeddedness in nature or the earth, was Descartes's goal. David Le Breton (2000) saw the separation of mind and body, and the derogation of the latter, as fundamental to modern Western culture and as being consummated in the seventeenth century. John Locke (1690) asserted that liberty and individuality must be based on ownership of private property and "improvement" - what we typically call development--of nature which, without such improvement, is waste (Rifkin, 2004, p. 100). For Locke, the right to own private property imposed the obligation to improve it. "The negation of nature is the way to happiness," according to Locke (Locke, 1690, as cited in Rifkin, 2004, p.100). The centrality of the human-nature rift in Locke's enormously influential conception of freedom and progress could not be clearer.

Nikolai Genov (2018), a sociologist at the Berlin Free University, argues, in Challenges of Individualization, that the rise of individualism carries a price. Specifically, individualization can come at the expense of various forms of common good in general, and of various forms of human solidarity in particular (Genov, 2018). We need to go beyond Genov's excellent point, acknowledging, not only the individual's embeddedness in and obligation to the human community, but also humanity's inextricable entanglement in the entire biosphere. Authentic sustainability will demand working in a community larger than that of humanity. However, it must also be made clear that concern for the needs of the earth does not require ignoring human needs. On the contrary, the two are complementary, since the earth is the source of all the wherewithal with which human needs will be met. Because many early modern thinkers defined nature, or the earth, as essentially a reservoir of resources to be exploited, or developed, for human purposes, and no doubt also because human power to degrade nature was still relatively small, the question of sustainability was virtually impossible to ask. Now, with natural systems showing definite 
signs of breakdown, the question ignored or repressed by our prevailing paradigm of knowledge and progress must be at the basis of our thinking about sustainability. Viewing nature as mere dead extension, or just matter in motion, made its ruthless exploitation seem legitimate. What are the material, socio-cultural, and psychological costs of humanity's alienation from nature?

\section{Causes of Alienation from Nature and the Body}

A number of precursors or practitioners of eco-psychology have given interesting explanations of the causes and consequences of alienation from nature and the body. Decades ago, Ernst Becker (1973) attributed many modern problems to the determination to dominate and control nature, and he linked that impulse to the fear of death. Death is associated with nature and the body, and, as we have seen, modern science was born out of the ambition to control and transcend biological reality (Becker, 1973). The body itself, given its concrete connection with the earth, was regarded as a limitation to be overcome by the operations of the mind. The mind, of course, was believed to operate independently of and above the body. Much more recently, in his 2016 book, Death and Mastery: Psychoanalytic Drive Theory and the Subject of Late Capitalism, Benjamin Fong elaborates on Becker's connection of the will to mastery with fear of death. Fong understands the desire for mastery or control as a would-be antidote to the fear of surprise, disorder, and, ultimately, of death. The drive to mastery implies denigrating and transcending what evolutionary biologist E. O. Wilson (1984) termed humanity's innate biophilia, or emotional involvement with/in all of earthly life. More recently, Clemens Arvay (2018) emphasized the healing power of the biophilia effect. Arvay extended the body of literature validating Wilson's (1984) biophilia hypothesis and elaborating on the benefits of healing the separation of humans from nature. Arvay's work is part of a growing body of research documenting these benefits. Such healing would, it seems, be a very constructive form of development.

Phillip Sherrard (1992) enriches our understanding of the modern mindset by associating individualism with the ecological crisis. He argues that the modern individual is encouraged to believe himself or herself to be the autocratic, omnipotent ruler of his or her own affairs and of the surrounding world. The prevailing view of the subject, or self, implies that it is situated in an abstract "space" separate from and above nature. Our commitment to this kind of individualism conflicts with ecological sanity (Gomes \& Kanner, 1995). Eco-philosopher Paul Shepard (1991) adds urbanization to the modern trends that deepen the rift between humans and nature. City life, he points out, places us in an environment dominated by human artifacts, exaggerating our control of nature and suggesting that we can live largely without it. Non-urban nature thus becomes "scenery," with only recreational or esthetic significance. This reinforces our actual detachment from it. In cities, we are no longer aware of being IN nature.

Mainstream modernity is heavily invested in discourses and practical methods promising mastery. This investment has required derogation of the body and of places, of ecological specificities. The replacement of direct awareness by representations of, discourse about, and technologically assisted perception of phenomena and events in the real world is perhaps the fundamental theoretical and practical problem of modernity. 
Paul Virilio (1989) makes a very useful point when he says that since the European Renaissance, the logistics of modern perception have been undercutting natural perception. The power of modern epistemology depends crucially on abstraction, which devalues sensual, bodily experience of the world. Eco-psychology and phenomenology seek to restore the primacy of such experience.

\section{Phenomenological Approach}

Perception is the focus of an excellent recent article by Jessica Belue Buckley (2013). She outlines a phenomenological approach to restoring a mindful, sustainable relationship with nature. Living sustainably implies a certain way of perceiving the earth and our relation to it. Such perception leads to concrete choices informed by that perception (Buckley, 2013). Buckley begins by analyzing some elements of our current language that imply the lack of such a relationship. She points out, for example, that we speak of throwing trash "out" or "away." This clearly suggests that the trash will no longer be connected to us in a place that we inhabit, that it will be consigned to an abstract nonplace. Mindful contemplation of reality would recognize that there is no such abstract space that is separate from us and immune to being damaged by us. The concept of the circular economy seems to represent a move toward theorizing a sustainable economic paradigm (Sustainable Management School Switzerland Business School, 2019).

Buckley's (2013) phenomenological account reminds us of our own actual experiences of connectedness with nature. Mushroom hunting in the woods, hiking and fishing in the mountains, lying at night under the stars in places far from urban light pollution, cultivating and harvesting vegetables and other crops for home consumption, all are potential models for an intense experience of our embeddedness in the earth. One of us lived as a child on three acres where most of what was eaten was grown or raised, organic waste was composted, and all family members contributed labor. We now realize that this was much closer to sustainability than what we have achieved, now, in suburbia. We can be intensely mindful of our earth-embeddedness as we watch the birdlife and trees in our yard and walk around our neighborhood ponds and the nearby lake. Close attentiveness reveals an amazing wealth of wildlife and plant life even here, in the suburbs. How would we find our way back to an overall practically sustainable life? How can keeping nature in mind lead to living sustainably in/on the earth? We buy organic food whenever possible; we shop at the local farmers' market; we eat mostly plant-based food; we exercise outdoors, trying to be mindful of our bodies in interaction with the earth; we use LED light bulbs and energy-efficient household appliances; we use reusable grocery bags, and we have installed energy-saving insulation and windows in our house. We have only battery-powered yard equipment, and we have joined a coalition of citizens and business/community groups that promotes the greening of our city. We do not pretend that these choices have made our lifestyle fully sustainable, but they are all small moves toward that goal, and they are also exercises of mindfulness that contribute to a change in our overall awareness. Taking such measures has changed our way of thinking, motivating us to make further choices and to redefine our needs with those of all of humanity and of the earth in mind. The phenomenology of our way of inhabiting the earth is changing. 


\section{Crucial Role of Emotion}

There are signs in contemporary cognitive science that the mind-body, humanity-nature rift decried by eco-psychologists and others can be closed-healed. In fact, there is a growing body of evidence that the split never corresponded to any reality. It was, rather, an intellectual convenience, a myth necessary to the achievement of vastly greater material power to achieve a certain idea of development. What seemed to lay the groundwork for a cognitive and material utopia has brought us close to earthly dystopia. In fact, it appears that the mind is a bodily function, that it never really promised transcendence of our bodily, earthly existence. Antonio Damasio's (1994) neurobiological studies demonstrate that thought finds its motivation and its meaning in the body, the emotions, and the environment-physical and social. Thinking must be energized by motives: by emotions or desires. Furthermore, world-renowned primatologist Franz De Waal (2010), in The Age of Empathy, asserts that modern Western philosophy has been obsessively preoccupied with what supposedly places humans "above" the animals and "frees" the mind from entanglement with the body, the emotions, and the social group. De Wall (2009) also argues that the separation of reason and emotion is false, that, in fact, affect or emotion is primary and must be engaged to motivate "rational" choices. This erroneous dichotomy has underwritten the modern philosophical commitment to the primacy and the viability of the autonomous individual. David Le Breton (2000) makes the complementary point that the radical, bierarchical separation of mind and body is fundamental to modernity and is an artifact of the early modern period. E. O. Wilson (2004) makes the provocative point that our urge for transcendence may be a maladaptive use of a capacity that was once adaptive, but for a different purpose.

Jonathan Haidt (2006), too, in The Happiness Hypothesis, argues that reason, which we think of as a purely mental capacity, is inextricably dependent on the body and the emotions. This tendency in Western thought goes back at least as far as Plato's Timaeus, in which a rationalist fantasy of subjugating the emotions is described (Haidt, 2006). The emotion-cognition dichotomy, however, can now be seen as nonsense, according to Haidt (2006). Emotion, too, is information processing. Reason and emotion are really two different kinds, or phases, of cognition. Haidt makes another point which is crucial for linking socio-cultural and psychological perceptions with sustainability: affect, or emotion, is more closely and powerfully connected to motivation, and thereby to action, than is thinking. Affect directs and focuses thought and action (Haidt, 2006).

These elucidations of the unity of mind, body, and emotions, and even of humanity's organic connections with the animal world, enable us to return better informed to Buckley's (2013) phenomenological evocation of the actual experience of our connection with the earth. In this light, the issue becomes one of emotion: what do we love? How do we experience, emotionally, both the sense of unity with, and the sense of loss of, nature? This approach also further illuminates the eco-psychological insight that alienation from the earth, or nature, creates a sense of loss. The concrete emotional experience of love and loss, it seems to us, must serve as motivation for both theoretical and practical progress toward true sustainability. Here, we can return, too, to Abram's (1997) valuation of sensual-bodily and emotional-experience over abstract, 
supposedly disembodied, knowledge.

\section{Some Statistics}

The need for a style of awareness favoring sustainability, and a sustainable conception of development, along with practical, concrete moves toward sustainability is obvious. Many relevant statistics are horrifying. China emits 10,357 metric tons of carbon dioxide, with the United States, India, Russia, and Japan close behind. Humancaused emissions of carbon dioxide need to fall $45 \%$ from 2010 levels by 2030 and reach net-zero around 2050 to limit climate change catastrophe. Energy is the dominant contributor to climate change, accounting for around $60 \%$ of total global greenhouse gas emissions. Lighting accounts for $15 \%$ of global electricity use. Switching to LEDs will use $90 \%$ less energy than incandescent lights, and such bulbs last far longer. Seventy percent of the world is covered by water, yet only $2.5 \%$ of it is fresh, and only $1 \%$ of it is easily accessible for human use. Water use has grown at more than twice the rate of population increase in the last century. The use of water-efficient fittings and fixtures has the ability to cut water use in homes by $45 \%$. If the entire world ate like the average American, there would not be enough water in the world to sustain the global population. Recycling one ton of paper saves 2,584 liters of oil, 26,498 liters of water and 2.5 cubic meters of landfill space (Sustainability Management School Switzerland Business School, 2019).

\section{Conclusions}

All of these numbers, and many more, both illuminate the desperation of our situation and provide reasons for hope. They imply choices that will make significant contributions to the achievement of sustainability. It seems possible that anthropogenic climate change is the problem that, finally, forcefully, tells us two crucial truths: that the earth is a closed, circular system, in which the good or bad consequences of our way of living will come back to us, and that "sustainability" means survival not only for us, but also for the ecological conditions in which any of what we regard as fundamental human needs can be met. For arguably the first point in the history of the earth, human behavior is a deciding factor in determining the future state of the planet and its viability as human habitat (Nickerson, 2002). What eco-psychology and phenomenology can provide goes beyond citing statistics, which can be more discouraging than inspiring, and may point the way toward an experiential healing of the rift between humanity and nature. Such experienced healing may well lead to the conception of a new paradigm, combining a new mindset through a restoration of embeddedness in body and earth. It is clear that an intense emotional response to our experience of nature and to the prospect of losing itbiophilia, in other words--must motivate our choices of sustainable practices. In order to be a viable human habitat, the earth must also be a viable habitat for the other life forms with which we have co-evolved. In his survey of human cultural evolution, Chris Gosden (2003) questions the idea that the course of human development has been continuous and progressive. "Gaining a really long-term sense of what it means to be human throws all recent lifestyles into perspective: our current, mass-consuming world is new, 
temporary, and fragile. It will pass away to be replaced by other arrangements" (p. 29). Clearly, those arrangements must be truly sustainable.

\section{References}

Abram, D. (1997). The Spell of the Sensuous: Perception and Language in a More-Than-Human World. New York: Vintage Books.

Arvay, C. (2018). The Biophilia Effect: A Scientific and Spiritual Exploration of the Healing Bond Between Humans and Nature. Louisville, CO: Sounds True Incorporated.

Bacon, F. (1902). Novum Organum. Devey, J. (Ed.). New York: P. F. Collier.

Beck, U. (2010). A God of One's Own : Religion's Capacity for Peace and Potential for Violence. (R. Livingstone, Trans). Cambridge, NJ: Polity. (Original work published 2010).

Becker, E. (1973). The Denial of Death. New York: The Free Press.

Buckley, J. (2013). "Re-storing the Earth: A Phenomenological Study of Living Sustainably." Phenomenology \& Practice, 7, (2), 19-40.

Damasio, A. (1994). Descartes' Error: Emotion, Reason, and the Human Brain. New York: Penguin.

De Waal, F. (2009). Primates and Philosophers: How Morality Evolved. Princeton, NJ: Princeton University Press.

De Waal, F. (2010). The Age of Empathy: Nature's Lessons for a Kinder Society. New York: Crown/Random House.

Descartes, R. (1901). Meditations on First Philosophy. Veitch, J. (Trans.). New York: Classical Library. (Original work published 1647).

Descartes, R. (1637). Discours de la méthode. Leiden: Imprimerie de Ian Maire.

Fong, B. (2016). Death and Mastery: Psychoanalytic Drive Theory and the Subject of Late Capitalism. New York: Columbia University Press.

Genov, N. (2018). Challenges of Individualization. London: Palgrave Macmillan.

Gomes, Mary E., \& Kanner, A. (1995). "The Rape of the Well-Maidens: Feminist Psychology and the Environmental Crisis." In Roszak, T., Gomes, M., \& Kanner, A. (Eds.). Ecopsychology: Restoring the Earth, Healing the Mind (pp. 11-121). San Francisco: Sierra Club Books.

Gosden, C. (2003). Prehistory: A Very Short Introduction. Oxford, UK, Oxford University Press.

Haidt, J. (2006). The Happiness Hypothesis: Finding Modern Truth in Ancient Wisdom. New York: Basic Books.

Latour, B. (1993). We Have Never Been Modern. (Porter, C., Trans.) Cambridge, Massachusetts: Harvard University Press. (Original work published 1991).

Le Breton, D. (2000). Anthropologie du corps et modernité. Paris: Presses Universitaires de France.

Merchant, C. (1989). The Death of Nature: Women, Ecology, and the Scientific Revolution. San Francisco: Harper.

Nickerson, R. (2002). Psychology and Environmental Change. Mahwah, NJ: L. Erlbaum Associates.

Plumwood, V. (1993). Feminism and the Mastery of Nature. London: Routledge.

Rifkin, J. (2004). The European Dream. New York: Jeremy P. Tarcher/Penguin.

Sheldrake, R. (1994). The Rebirth of Nature: The Greening of Science and God. Rochester, Vermont: Park Street Press.

Shepard, P. (1991). Man in the Landscape: A Historic View of the Esthetics of Nature. College Station: Texas A\&M University Press.

Sherrard, P. (1992). Human Image: World Image, the Death and Resurrection of Sacred Cosmology. Ipswich, England: Golgonooza Press.

Solomon, J. (1998). Objectivity in the Making: Francis Bacon and the Politics of Inquiry. Baltimore: The Johns Hopkins University Press.

Sustainable Management School Switzerland Business School (2019). "30 Interesting Facts about Sustainability." Retrieved from https://SUMAS.ch

Virilio, P. (1989). War and Cinema: The Logistics of Perception. (Camiller, P. Trans.). London: Verso. (Original work published 1984).

Wilson, E. O. (1984). Biophilia: The Human Bond with Other Species. Cambridge MA: Harvard University Press.

Wilson, E. O. (2004). On Human Nature. Cambridge, MA: Harvard University Press.

World Commission on Environment and Development, (1987). Our Common Future. (Also known as the Brundtland Report.) United Nations, Oxford University Press. 